\title{
Lung Cancer pT2a TNM Finding v7
}

National Cancer Institute

\section{Source}

National Cancer Institute. Lung CancerpT2a TNM Finding v7. NCI Thesaurus. Code C88872.

Lung cancer with a tumor size more than $3 \mathrm{~cm}$ but $5 \mathrm{~cm}$ or less in greatest dimension. (from AJCC 7th Ed.) 